\title{
THE REALITY OF AMERICAN NATION SLAVERY IN THE NOVEL INCIDENTS IN THE LIFE OF A SLAVE GIRL BY HARRIET ANN JACOBS
}

\author{
Abbas \\ The Culture Science Faculty of Hasanuddin University \\ abbas@unhas.ac.id
}

\begin{abstract}
This article discusses the social facts experienced by Americans in literature, especially novel. Literary work as a social documentation imagined by the author is a reflection of the values of a nation or ethnicity. The main objective of research is to trace the reality of slavery that occurred in America as a social fact in literary works. This research is useful in strengthening the sociological aspects of literary works as well as proving that literary works save a social reality at the time so that readers are able to judge literary works not merely as fiction, but also as social documentation. The writer in this study uses one of the literary research methods, namely Genetic Structuralism Approach. This method emphasizes three main aspects, namely literary work, the background of the author's life, and social reality. Novel Incidents In The Life Of A Slave Girl written by Harriet Ann Jacobs in 1858 was used as primary research data, then a number of references about the author's social background and the reality of slavery in the history of the American nation became secondary data. Primary and secondary research data obtained through literature study. Based on the results of this study found the events of slavery in the history of the American nation. Slavery was the act of white Americans forcibly employing black Negroes on the lands of plantation and agricultural also mining areas. Slavery is a valuable lesson for Americans in protecting human rights today as well as a historic lesson in building the American national spirit, namely freedom, independence, and democracy. The reality of slavery is reflected in the novel Incidents In The Life Of A Slave Girl as well as the life experience of its author, Harriet Ann Jacobs.
\end{abstract}

Keywords: Slavery, America, Structuralism Genetic, Novel Incidents In The Life Of A Slave Girl

\section{INTRODUCTION}

The American nation is a nation that is unique compared to other nations. The uniqueness includes the diversity of social and cultural background, the acculturation of various ethnicities and nations, the first democratic country that stands on the constitution, and the history journey that holds some important events. The American nation is a gathering place for various ethnicities and nations in the world ranging from the European continent to America, including Anglo-Saxon, French, Dutch, Spanish, Swedish, German, Italian, Russian, African nations, Asian nations, and Latin American nations. All of these nations have been emigrated from their home country and built a civilization as part of American history and eventually became the identity of the American nation.

Nations in America since the era of colonialism by Britain, France, Spain, Dutch, and Germany until the current time have kept their identity as part of the history of the American people. One of the social realities that became the identity of the American nation was slavery as reflected in the novel Incidents In The Life Of A Slave Girl written by Harriet Ann Jacobs for five years from 1853 to 1858 . Slavery was the act of white people who traded people black Negroes to be owned and forced to work on the lands of 


\section{7 | JURNAL ILMU BUDAY}

Volume 8, Nomor 1, Juni 2020

plantation and agricultural lands also mining.

The identity of the American Nation is an important issue to be investigated as part of the ethno-social description of society traced in literary works. The condition of society as part of social reality is seen as a fact in the history of that society. This fact has universal values which are known in the study of literary sociology as vision dumonde or worldview. This research is important in exploring vision dumonde on literary works that can be absorbed as lessons of human life throughout the ages in the form of universal values. These values become the historical reality of a nation as a universal worldview.

The worldview as universal values in literary works has been extensively studied beforehand in various forms of scientific writing such as dissertations, books, theses, articles, and others. Some of the results of literary sociology-based research that can be mentioned here are a dissertation by Sumarwati Kramadibrata with the title Citra Wanita Amerika Dalam Beberapa Karya Sastra Pilihan Sinclair Lewis or The Image of American Women in Selected Literary Works by Sinclair Lewis, Book of Kritik Sastra Feminis: Teori dan Aplikasinya or Feminist Literary Criticism: Theory and Its Application by Sugihasturi and Suharto with the title of the Chapters of Pokok-Pokok Pikiran Feminis Novel Sitti Nurbaya or Feminist Thought Novels Sitti Nurbaya, Thesis by Muawinatul Rahmah with the title Social Criticism in Orwell 'Down and Out in Paris and London, and an article by Abbas entitled The Portrayed British Women in Austen's Pride and Prejudice.

Kramadibrata (1995) in her dissertation described the existence of American women and feminist thoughts reflected in five American literary works written by Sinclair Lewis with a conclusion that the author's social background naturally influences the facts of her imagination in literary works. Then, Sugihasturi and Suharto (2016) in their book export the thoughts, attitudes, actions, physical depictions, and social environments of traditional Indonesian women as played by a fictional character of Sitti Nurbaya in the novel which concluded that the role of religion and tradition was very strong in building a tradition of subordination towards women. Furthermore, Rahmah (2017) in his thesis described the poverty that plagued European society in the twentieth century as a result of the events of the First World War is a social fact in the novel Down and Out in Paris and London which concluded that people in big cities like London in England and Paris in France suffered great suffering from disease, hunger, discrimination, fraud, and robbery. Abbas (2018) in his article discusses the reality of British society about the social life, mindset, and character of British women in the nineteenth century in a literary work entitled Jane Austen's Pride and Prejudice which emphasizes that English law which removes inheritance rights for girls makes parents trying to marry their daughter to a rich man of high social status.

The relevance of this research to all the previous studies that have been explained is to explore universal values in literary works as a social reality in society. In literature, these universal values are seen as sociological elements of literature. Although there are similarities in exploratory sociology in literature, but this study has differences with a number of previous studies. Differences can be found in the object of study and issues explored. The object of this study is a novel written by an American author, Harriet Ann Jacobs. The issue explored as a social fact is slavery in America which is different from the previously mentioned research 


\section{8 | JURNAL ILMU BUDAY}

Volume 8, Nomor 1, Juni 2020

that focuses on feminist issues, gender relations, poverty, and law.

The main objective of this research is seen from the aspects of science and social pragmatics is to strengthen the scientific theory of literature that high literary works have sociological elements associated with aspects of human life that have never been abandoned by time and even able to encourage the birth of a new civilization, as well prove that literary works are part of the social documentation of a particular nation or ethnicity. This research is expected to be useful for literary reviewers and literary readers. Literature reviewers can make references and comparisons of information in sociological literature research. This research can also enrich the literary readers' insight that literary works are imaginative works that have universal values and documentation of social facts that have occurred in the community.

Based on all the previous explanations that literature is the author's imaginative product that seeks to document certain social facts in society by bringing up universal values as worldviews, the writer is interested in exploring social reality and universal values of literature in this study. The sociological issue of research is finding the reality of American slavery in the novel.

\section{METHOD}

This research is a literary study based on sociological elements of literary works. Sociology comes from Ancient Greek, namely socius and logos. Socius means collection together in English means society, while logos means knowledge that is empirical and rational. Literature is taken from Sanskrit, namely sas means to direct or teach and tra means a tool. So, literature in general can be understood as the work of the author's imaginative work that directs humans to the values that can be used as guidelines or lessons in life

The relationship of sociology and literature can be seen from the object and its benefits, namely humans. Sociology is the study of all problems related to humans in a collection or community or society, while literary works come from social problems in human life that are processed by the author's imagination to aware humans. Based on this relationship, the writer understands that literary sociology is a study that explores the reflection of social problems in human life, society, ethnicity, nation that grows human consciousness collectively on universal values.

According to Ratna (2013: 3-8), the sociology of literature has emerged since the era of Ancient Greece around five centuries BC, which was sparked by Plato and Aristotle in the concept of mimesis which is said that literary works are actually imitations or paintings of the conditions of society that lay behind them. This concept was later developed in a number of Marxist theories which gave rise to various forms of literary sociology research that Taine coined. Taine's sociological thinking was later developed by Lucien Goldmann from France into a model of literary research under the name Genetic Structuralism Approach (Faruk, 2014: 56-62).

Referring to the relationship of sociology with literature, then literature can be seen as not autonomous because literary works do not appear suddenly, but through a sociological process. The view that literature is social documentation is the basis of the thought of literary experts such as Goldmann (1981: 10-15) on literary genetics. He thought that the origin of literary works came from the structure of society and the results of human adaptation to the environment. Based on this thinking, the writer concludes that 


\section{9 | JURNAL ILMU BUDAY}

there are three main elements in the Genetic Structuralism research method, namely the literary structure, the author's social background in the work, and the social reality absorbed by the author.

The process of literary creation starts from social reality that is permeated by the author, then the reality is processed according to the imagination of the author, then the author produces creativity in the form of literary works, and finally transforms into a worldview that carries universal values. It can be described this process in the form of a flow as follows:

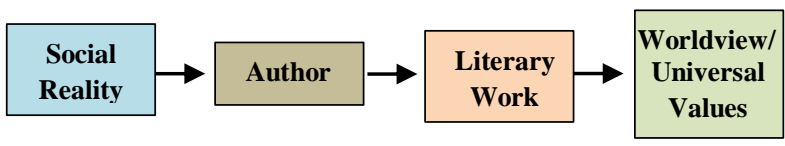

Some problems that arise in human life as a social reality that takes place in a society in a certain period of time. This reality can take the form of human action in various forms such as slavery, colonialism, oppression, religious conflict, resistance, adventure, and others. Massive human action has the potential to become an issue in aspects of culture, politics, economics, religion, education, and others, which become the historical documents of group, ethnic, and nation. It is considered as a social fact attached to a particular society and then documented by the author in literary works.

Literary works are created through an imaginative process by the author who geniusly processes facts into fiction. The author consciously creates literary works and even requires years of reflection to permeate a reality that occurs in him or in society. This reality is seen by the author as an aspiration that grows and develops in society as Goldmann once said (1977: 1520) that the author is naturally a member of the community who has social interaction for a long time. Worldview or vision dumonde of an author does not appear suddenly, but takes place slowly until the tangible form of high-quality literary works.

The issue in this literary sociology research is slavery so the writer needs to establish theories or limits on the concepts of slaves and slavery used by experts. According to Hille (2020), a slave is a person who is owned by a free person based on the law and becomes part of the owner's property. Then, slavery according to Widyaningrum (2019) referred to the notion of the United Nations is the status or condition in which a person has power and ownership over another person, slaves are defined as people who are controlled and owned to be employed. Based on these two opinions, the writer limits the notion of slavery in relation to this research is an act of forcibly employing black Negroes as part of private property of white people. This action is an important event that has occurred in the history of the American nation because it has a wide impact on various aspects of social life and has received global attention as a universal issue.

The data source of this study refers to the data emphasized in the Genetic Structuralism Approach method, namely primary and secondary data. Primary data is the object of study in the form of literary works as in general literary research, while secondary data is a number of information that includes the author's social background and social reality as the genetics of the literary work under study. The primary data of this study is the novel Incidents In The Life Of A Slave Girl by Harriet Ann Jacobs. Then, secondary data is a number of references that describe the background of the author's social life through an online site written by Nittle (2019), and the social reality of American slavery in An Outline of American History (1992) and Garis Besar Sejarah Amerika (2004). 
Research data processing refers to the research formulation of genetic structuralism. Endraswara (2013: 62) suggests three steps in genetic structuralism research, namely the first is to study literary works intrinsically, the second is to explore the background of the author's social life related to the meaning of the literary works, and the third is to reveal social facts and the history of the society that is underlying the literary work. The writer constructs these steps into the study chart below:

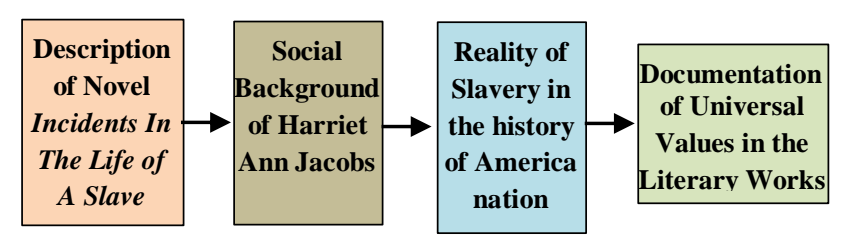

In the chart above, the writer adds documentation of universal values in literature as a fourth step. The relationship between universal values that occur in the history of a nation with literary stories is seen as the ultimate goal of research in sociological literature. The author's imagination creation process is from fact to fiction, then the scientific study of literature through the reverse process from fiction to facts. It shows that the factual documentation in fiction is an important relationship spelled out in the sociology of literature as a result of scientific research as well as being a scientific responsibility of a researcher towards the reader.

\section{RESULT AND DISCUSSION}

As the literature research procedure on the Genetic Structuralism Approach has been explained, the first step is to describe the literary work, then the second is to explore author's social background, afterward the third is to explain the research issue as a social reality. All information obtained from these three aspects is categorized as research results, while the discussion is documentation of the reality of American slavery in literary works as universal values.

\section{Result of The Research}

\subsection{Description of Novel Incidents In The} Life Of A Slave Girl

This novel describes the life experiences of slave families and people enslaved by whites. Slaves did not have freedom, did not have natural rights, and had to work all the time in the employer's house and on farms and even their children were also born slaves. The status of slaves was hereditary and inherited from white masters. This event occurred around the 1800s which in the novel mentioned the time setting of 1813 in the North Carolina region where slaves fled to various cities such as Brooklyn, Manhattan, New York, Massachusetts, and California.

A slave family with two young children, a daughter named Harriet Jacobs or her nickname Linda and a son named Willie. They lived in a white employer's house, her father died and followed her mother when Linda was only six years old. Linda and Willie who are still kids are maintained by Mrs. Nash, who treated him well, taught him how to sew, write and read English. A few years later Mrs. Nash died, Linda and Willie were taken back by Emily Flint's family, which was her parents' employer. Linda and Willie were considered to be old enough to be employed as slaves and they realized that the status of slaves as their parents and grandparents had remained hereditary.

Dr. Flint and his wife named Mrs. Flint or Cora treated Linda and Willie cruelly and was prohibited from communicating with outsiders. Dr. Flint likes Linda and even tries to rape her. This incident made Mrs. Flint was jealous and tortured Linda. A white young man named Mr. Sands felt sorry for Linda's anguish, who finally had a secret relationship until Linda gave birth to a son named Benny 


\section{1 | JURNAL ILMU BUDAY}

Volume 8, Nomor 1, Juni 2020

and a daughter named Ellen. Dr. Flint was angry and then forced Linda to break with Mr. Sands and told her to live in a house with her children as a mistress. Linda refused and chose to be hired on the plantation with her two children, "I'am ready to go to the plantation, Sir" (Jacobs, 2004: 53).

Dr. Flint tortured Linda even more and she could no longer bear the pain. Linda decided to run away. Dr. Flint issued a contest that anyone who found Linda would be given a prize money. Linda kept moving from one house to another, from one city to another to save herself. Linda continued to run north in Philadelphia, Brooklyn, New York, Boston to Manhattan. Linda's escape lasted for decades until she met her daughter, Ellen in New York and gathered with her son, Benny in Boston.

Dr. Flint died, but the Flint's family continued to hunt Linda and her children as runaway slaves. Linda and her two children returned to fugitive then left Manhattan and fled to New Hampshire. They live in a good Bruce family. Mrs. Bruce took the initiative to negotiate with Dr. Flint's son in law named Mr. Dodge. Bruce's family managed to buy Linda and her two children from the Flint family for 300 dollars. Bruce's family then frees Linda and her children from slavery and becomes a free human being.

\subsection{The Social Background of Harriet Ann Jacobs' Life}

In this section, the writer traces the background of Harriet Ann Jacobs's life to the story of slavery of the Negroes in America. Harriet Ann Jacobs was born in Edenton, North Carolina, in 1813. She was a black woman who born within a slave family in America. She only realized that she was also a slave when she was 6 years old, her mother died. The American situation at that time, especially in the south, continued the tradition of slavery by white people who were descended from European immigrants against black people of Negroes. She experienced and witnessed the lives of slaves who did not have social rights, worked around the time except for Christmas and the welcome of the New Year, slaves were made as property of employers that could be traded or even inherited, they had slave status for generations, and they had to work hard to satisfy their employers.

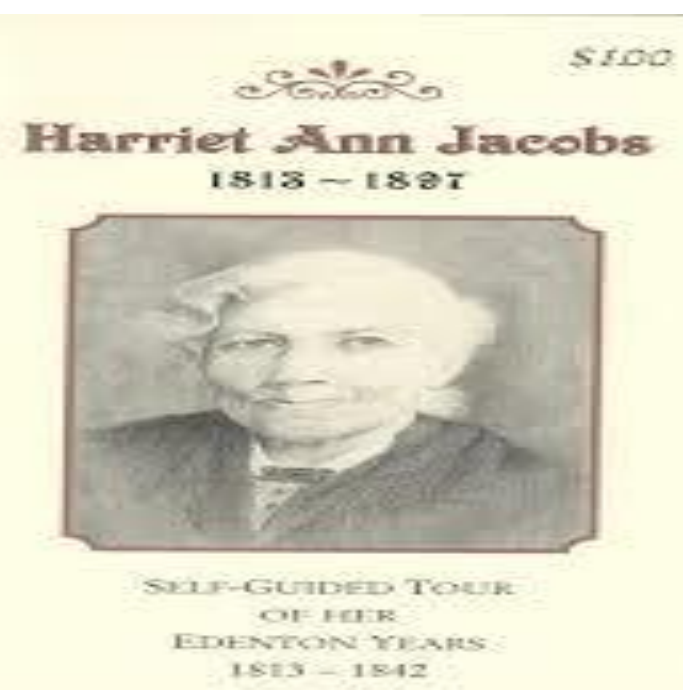

Picture 1. Harriet Ann Jacobs was a slave in America who run away and became an author of literary works.

(Source:

https://www.google.com/search?q=harriet+ ann + jacobs+biography\&safe $=$ strict $\& s a=X \& s x s r f=$ ALeKk01BsjLh_BK7HelMrYPQFuM7etrR1Q:158 4022471716 accessed on March 12, 2020 at 10.32 p.m.)

As a child, Harriet had the good fortune because she had been taught to read and write English also sew by her employer named Margaret Horniblow. She died when Harriet was twelve years old. Harriet along with her brother named John $\mathrm{S}$. Jacobs later became a slave of her father's employer named Dr. James Norcom. Not long after, her father passed away. Harriet and her brother suffered greatly because they were forced to work hard all day and suffered ill treatment from Dr. James and his family. Harriet secretly had an affair with a young white man 


\section{2 | JURNAL ILMU BUDAY}

Volume 8, Nomor 1, Juni 2020

named Samuel Tredwell Sawyer to give birth a son named Joseph and a daughter named Louisa Matilda. These two children were made by Dr. James as his treasure in the form of slaves.

The ability to read and write was Harriet's main asset in voicing her social awareness in order to free the Negroes from the slavery of white people. Her brother and uncle were involved in supporting her struggle. In 1838 at the age of 25, Harriet escaped from her employer and moved places until she arrived in Philadelphia and then New York in 1849. Her awareness of freedom grew stronger when she helped in the newspaper office of an American anti-slavery figure named Frederick Douglas.

According to Nittle (2019), Harriet tried to build awareness of Americans on the elimination of slavery practices through literary works such as the novel Incidents In The Life Of A Slave Girl which began writing in 1853 and finished in 1858. She also received support from anti-slavery writers like Harriet Becher Stowe. Harriet Ann Jacobs died on March 7, 1897 and she still managed to witness the American Civil War of 1861-1865 which was won by anti-slavery groups. This war led to the birth of Amendment XIII of the American Constitution of 1865 concerning the abolition of slavery, Amendment XIV of 1868 concerning the granting of suffrage for black people, and Amendment XV of 1869 concerning granting suffrage without being limited by race and color.

\subsection{The Reality of Slavery in American Nation}

In this section, the writer describes an important event in the history of the American nation, namely slavery as a social fact. The history of slavery in America began with the arrival of the Dutch and British who brought black Negro from Africa around the 1600s. They are traded and employed on plantation lands. Slave goes to hereditary status. African Negroes who were made the first slaves arrived in Jamestown, Virginia in 1612. Slaves then became a commodity of trade increased since 1660 and reached its peak when the Americans underwent Industrial Revolution in 1790. They were generally employed on cotton and sugar cane plantations in the southern United States, including Texas, Louisiana, Missouri, Alabama, South Carolina, North Carolina, Alabama, and Mississippi.

International slave trade was abolished in 1808 so that northern regions such as New York, Massachusetts, Ohio, Maryland, and Pennsylvania shifted the slavery system to the labor system, while the southern region maintained the slavery system as an important commodity for the regional economy. Conflicts between a number of states in the pro-slavery south of America and anti-slavery north of America began to emerge as a political issue since 1830. According to Cineotta (2004: 167-168), around 46,274 white people in the southern region on average have 20 black slaves or a total of more than one million Negroes became slaves. The practice of slavery in 1840 increasingly developed into newly opened western American regions such as Nebraska, Wyoming, Dakota, and others. Slaves were forced to work, beaten, sold, and separated from their families. In 1850, several employers began to teach their slaves to read and write English and sewing skills like in Pennsylvania.

John Fremont of the Republican Party in 1856 urged that slavery be abolished immediately because it was inhumane and violated human rights. He then along with a number of political figures such as Salmon P. Chase, William Seward, and Abraham Lincoln spoke out loudly wanting to abolish slavery throughout America. An open conflict arose in 1857 


\section{3 | JURNAL ILMU BUDAY}

Volume 8, Nomor 1, Juni 2020

when a number of slaves fled from the south and entered Kansas, Wisconsin, Illinois, and were protected. However, the Supreme Court ruled that these slaves could not be released because they did not have citizenship status and had to be returned to their employers in the south.

The issue of slavery became an important political debate in the 1860 presidential election between Abraham Lincoln of the anti-slavery of the Republican Party and Stephen A. Douglas of the Democratic Party. Abraham Lincoln won and was sworn in as President of the United States on March 4, 1861 which resulted in eleven states in the southern region breaking away and forming a selfgovernment called the American Confederation by appointing Jefferson Davis as its president. This political conflict between anti-slavery groups and pro-slavery groups led America to the Civil War which began on 12 April 1861 until 14 April 1865.

The Civil War claimed the lives of millions of Americans who according to Olson (1992: 86-91) were the highest number of people killed in American history. This bloody conflict ended with a number of laws, namely the Enforcement Act of 1870 and the Amnesty Act of 1872 . Slavery was also abolished constitutionally through Amendment XIII of the American Constitution of 1865, although sentiment towards black people continued throughout the twenty-first century.

\section{Discussion}

The writer of this section explores the reflection of social reality or mirror the situation of American society against the fiction of the novel Incidents In The Life Of A Slave Girl by Harriet Ann Jacobs. The Americans have experienced an important event in history, the act of slavery by white Europeans against black Negro Africans. This action was legalized and institutionalized instead as a trade commodity to improve the regional economy. This incident lasted from 1612 to 1865 which reaped social, political, military, and its impacts are still felt today. This slavery event was documented in the novel written by Harriet Ann Jacobs for five years from 1853 to 1858 .

The main character in the novel is a slave girl named Harriet Jacobs called Linda. She and her brother, Willie, were born into a slave family and from the age of six, her mother died and was cared for by a nice white woman named Mrs. Nash. They are taught reading and writing also sewing skills. Social facts showed that the State of Pennsylvania in the 1800s had provided slaves with sewing skills as well as English reading and writing lessons.

After Mrs. Nash died, Harriet and Willie were taken to be employed as slaves by their father's employer, Dr. Flint. This situation also happened to the author, Harriet Ann Jacobs who at the age of six years, his mother died. She and her brother, John S. Jacobs, were cared for by the kind-hearted Margaret Horniblow. They are taught to read, write and sew. When Margaret Horniblow died, Harriet and John were taken by their father's employer, Dr. James Norcom to be slaves. In American history, slaves are inherited from generation to generation as experienced by Harriet Jacobs or Linda as fictional characters and Harriet Ann Jacobs as the author of this fiction.

Black people suffer from appalling conditions, many of whom are employed as slaves on cotton plantation and sugar cane fields in southern America, including Texas, Louisiana, Missouri, Alabama, South Carolina, North Carolina, Alabama, and Mississippi. This condition also occurs in a fictional story that describes Linda and all her family suffered because of slavery in the South American region, especially in North Carolina. This situation is reflected in the novel's story that describes 


\section{4 | JURNAL ILMU BUDAY}

Volume 8, Nomor 1, Juni 2020

the suffering of slaves and their plight in Edenton, North Carolina in the 1800s. Background of the life of the author, Harriet Ann Jacobs from 1813 to 1850 and her family also experienced the same thing that happened to the poor conditions of life of slaves in South America until 1865.

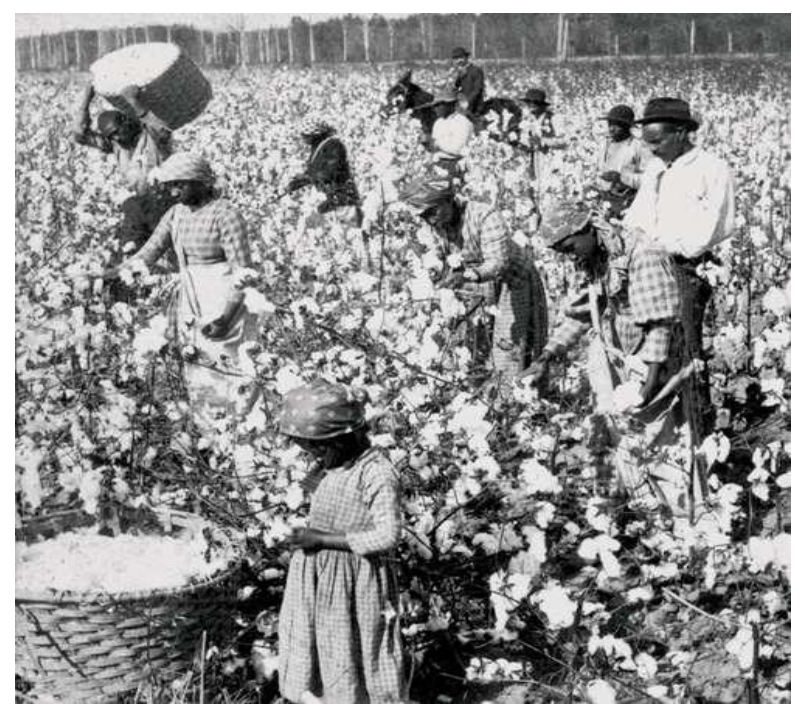

Picture 2. The condition of Negro black slaves employed on cotton plantations in Georgia, southern America.

(Source: $\quad$ https://cdn.britannica.com/30/138730050-312CBBAF/Slaves-cotton-Georgia.jpg accessed on March 12, 2020 at 4.10 p.m.)

North American regions such as New York, Massachusetts, Manhattan, Ohio, Maryland, Pennsylvania, since 1790 abolished the slavery system and liberated all Negro slaves. The northern states replaced the slavery forced labor system into a labor payroll system in line with the abolition of the international slave trade in 1808. The policy of liberation of slaves by states in the north of America resulted in many slaves from the southern region fleeing northward as slaves escaped which occurs in the novel. Linda escaped from her employer in North Carolina to the north in Philadelphia, Brooklyn, New York, Boston, and Manhattan to New Hampshire. She ran away to be free from suffering as a slave. The author of this novel, Harriet Ann Jacobs, at the age of 25, also ran away from her employer named Dr. James Norcom in 1838. She continued to run away to avoid the efforts of her employer to catch her back as a slave. In 1849 she arrived in New York and worked in the newspaper office of an American anti-slavery figure named Frederick Douglas. Harriet's awareness grew more about freedom, independence and human rights because she read a lot of books and articles in the Frederick Douglas library.

The American Civil War that lasted for five years between 11 states in the proslavery southern region and 23 states in the anti-slavery northern region ended in 1865 . The victory was won by the anti-slavery state group under the leadership of President Abraham Lincoln. The American Congress finally amended the constitution of 1865 which freed all black Negroes in America from slavery. Harriet Ann Jacobs as the author of the novel Incidents In The Life Of A Slave Girl also finally enjoyed her freedom as a slave and continued to write literary works documenting the Negroes as a result of acts of slavery. Slave liberation also occurred at the end of the novel's story, Linda was released from Dr. Flint's family slavery by a nice white family named Mrs. Bruce.

Slavery is a valuable lesson for Americans in protecting human rights today as well as a historic lesson in building the American national spirit, namely freedom, independence and democracy. The universal value that can be drawn from this slavery event is that the state must provide the freedom and independence of each of its citizens to ensure the sustainability of their national democracy. In harmony with this universal value, the worldview or vision dumonde of the novel Incidents in The Life of A Slave Girl which is associated with Harriet Ann Jacobs' social background as the author is the liberation of slaves and reconciliation between whites and blacks is the best way 


\section{5 | JURNAL ILMU BUDAY}

Volume 8, Nomor 1, Juni 2020

to sustain the life of the nation and prosper the national economy. Martin Luther King Junior (Cineotta, 2004: 346-349) in 1963 once said that I had a dream that at one time children of former slaves and children of former slave employers could sit together at one table, the fraternity table. This dream will gradually become a reality as the economic conditions of black Americans improve, that is, in 1965 their average income has reached 60 percent of the income level of white people.

\section{CONCLUSION}

Literary work has a strong historical value in documenting the social facts of a particular society or nation as the facts of slavery are reflected in the novel Incidents In The Life Of A Slave Girl by Harriet Ann Jacobs. This social fact was successfully revealed in this study through the sociological analysis of literature using the Genetic Structuralism research method. This sociological analysis scientifically proves that imaginative works in the form of literature have universal values that are capable of documenting social facts that have occurred in society so that literary works are part of the social documentation of a particular nation or ethnicity such as America.

Harriet Ann Jacobs in her novel through a fictional character named Harriet Jacobs or Linda tells the suffering and struggle of Negro black people from the slavery of white people as well as documentation of her life experience as a slave. She ran away from his employer and fought for his release. Slavery of black Negro Africans in America was legalized and institutionalized and made an economic commodity in human trafficking. They were employed forcibly and inhumanely to improve the economy of the colony, especially in the South American region. The legalization of slavery lasted from 1612 to 1865 which reaped social, political, military, and conflict impacts that are still felt today in the social life of the American nation.

Slavery is a valuable lesson for Americans in protecting human rights today as well as a historic lesson in building the American national spirit, namely freedom, independence and democracy. The universal value that can be taken from this slavery event is that the state must give freedom and independence to every citizen in order to guarantee the sustainability of a nation's democracy.

\section{BIBLIOGRAPHY}

Abbas. 2018. The Portrayed British Women In Austen's Pride and Prejudice. Proceeding International Multidisciplinary Academic Conference (IMAC) - Ipoh Malaysia, 21-22 March 2018.

Cineotta, Howard, et al. Tanpa tahun. Garis Besar Sejarah Amerika. Translated by Yusi A. Pareanom. 2004. Jakarta: Departemen Luar Negeri Amerika Serikat.

Endraswara, Suwardi. 2013. Metodologi Penelitian Sastra: Epistemologi, Model, Teori, dan Aplikasi. Yogyakarta: CAPS (Center for Academic Publishing Service).

Faruk. 2014. Pengantar Sosiologi Sastra, dari Strukturalisme Genetik sampai Post-modernisme. Yogyakarta: Pustaka Pelajar.

Goldmann, Lucien. 1977. Towards A Sociology of The Novel. London: Tavistock Publications.

Goldmann, Lucien. 1981. Method in the Sociology of Literature. London: Basil Blackwell Oxford.

Hille, Richard. 2020. Slavery. https://www.britannica.com/topic/slaver y-sociology/Historical-survey. 
Accessed on March 12, 2020 at 4.05 pm.

Jacobs, Harriet. 2004. Incidents In The Life Of A Slave Girl. New York: Townshend Press.

Kramadibrata, Sumarwati. 1995. "Citra Wanita Amerika Dalam Lima Karya Terbaik Sinclair Lewis". Dissertation of Doctor. Jakarta: Program Pascasarjana Universitas Indonesia.

Nittle, Nadra Kareem. 2019. Biography of Harriet Jacobs, Writer and Abolitionist. https://www.thoughtco.com/harrietjacobs-biography-4582597. Accessed on March 12, 2020 at 10.18 p.m.

Olson, Keith W. 1992. An Outline of American History. USA: University of Maryland.

Rahmah, Muawinatul. 2017. "Social Criticism In Orwell' Down and Out In Paris and London". Thesis of Undergraduate. Makassar: Jurusan Sastra Inggris FIB Universitas Hasanuddin.

Ratna, Nyoman Kutha. 2013. Pengantar Sosiologi Sastra, dari Strukturalisme Genetik sampai Post-modernisme. Yogyakarta: Pustaka Pelajar

Sugihastuti dan Suharto. 2016. Kritik Sastra Feminis, Teori dan Aplikasinya. Yogyakarta: Pustaka Pelajar.

Widyaningrum, Gita Laras. 2019. Mengenal empat jenis perbudakan di Afrika.

https://nationalgeographic.grid.id/read. Accessed on March 12, 2020 at 4.38 pm. 